\title{
“AGRO ACIMA DE TUDO, MINÉRIO ACIMA DE TODOS”: AS AMEAÇAS DO GOVERNO BOLSONARO ÀS ÁREAS LEGALMENTE PROTEGIDAS NA AMAZÔNIA
}

\author{
“AGRO SOBRE TODO, ORE SOBRE TODOS”:LAS AMENAZAS DEL GOBIERNO DE \\ BOLSONARO A ÁREAS LEGALMENTE PROTEGIDAS EN AMAZÔNIA
}

\author{
."AGRO ABOVE EVERYTHING, ORE ABOVE ALL":THE THREATS OF THE \\ BOLSONARO GOVERNMENT TO LEGALLY PROTECTED AREAS IN AMAZÔNIA
}

DOI: http://dx.doi.org/10.9771/gmed.v13i2.44866

\author{
Josiane Soares Santos ${ }^{1}$ \\ Everton Melo da Silva²
}

\begin{abstract}
Resumo: O artigo demonstra, através de revisão de literatura com análises no referencial marxiano e marxista, as atuais investidas do agronegócio e da mineração predatória na região Amazônica sob o comando político do Governo Bolsonaro. A expropriação das terras e territórios de povos tradicionais é um dos traços do desenvolvimento econômico capitalista no Brasil. Com o aprofundamento da crise do capital este tem requerido escalas crescentes de apropriação de bens naturais, como o minério de potássio, produto fundamental na fabricação de fertilizantes utilizados de produção de commodities agrícolas. Esse processo configura uma das ameaças do Governo Bolsonaro a essas populações em detrimento de uma determinada concepção de desenvolvimento econômico.
\end{abstract}

Palavras-chave: Agronegócio. Mineração. Governo Bolsonaro. Potássio. Povos tradicionais.

Resumen: El artículo demuestra, a través de una revisión de la literatura con análisis en el marco marxista y marxista, el actual embate de la actividad agroindustrial y minera en la región amazónica bajo el mando político del Gobierno de Bolsonaro. La expropiación de las tierras y territorios de los pueblos tradicionales es una de las características del desarrollo económico capitalista en Brasil. Con la profundización de la crisis del capital, se han requerido crecientes escalas de apropiación de bienes naturales, como el mineral de potasio, producto fundamental en la fabricación de fertilizantes utilizados en la producción de commodities agrícolas. Este proceso constituye una de las amenazas del gobierno de Bolsonaro a estas poblaciones a expensas de una cierta concepción del desarrollo económico.

Palabras clave Agroindustria. Minería. Gobierno de Bolsonaro. Potasio. Pueblos tradicionales.

Abstract: The article demonstrates, through literature review with analyses in the Marxian and Marxist frameworks, the current investments of agribusiness and mining activities in the Amazon region under the political command of the Bolsonaro Government. The expropriation of lands and territories of traditional peoples is one of the traits of capitalist economic development in Brazil. With the deepening of the capital crisis, it has required increasing scales of appropriation of natural goods, such as potassium ore, a fundamental product in the manufacture of fertilizers used in the production of agricultural commodities. This process constitutes one of the threats of the Bolsonaro Government to these populations to the detriment of a given conception of economic development.

Keywords: Agribusiness. Mining. Bolsonaro Government. Potassium. Traditional people. 
Introdução

Novembro de 2018 marcou, para a população brasileira, o prenúncio de um trágico período que, estupefatos, vemos desenrolar-se diante de nossos incrédulos olhos. O então candidato eleito Jair Messias Bolsonaro, antes mesmo de sua posse em 01 de janeiro de 2019, intensificou sua "metralhadora" de impropérios apontando em todas as direções e, após a posse, de fato, sua disposição para interferir em cada milímetro da composição dos ministérios não deixou margem para dúvida quanto ao direcionamento antidemocrático, neoliberal e de extrema-direita que marcaria sua permanência no cargo.

Nem os melhores analistas seriam capazes de prospectar, naquela ocasião, detalhes dessa tragédia, e uma marca que, apesar de sempre presente no perfil do Presidente, adquiriu proporções inimagináveis: seu caráter genocida. Ainda durante a campanha, Bolsonaro comprometeu-se em ampliar a posse de armas de fogo e, em diversos de seus atos administrativos, ao fazê-lo, tem compactuado com o aumento das mortes violentas no país ${ }^{3}$ - inclusive com a ascensão de organizações criminosas como as milícias com as quais, tudo indica, possui estreitos laços de colaboração e proximidade ${ }^{4}$. A naturalização das mortes violentas, portanto, não chega a surpreender inteiramente, mas, sem dúvida, nada se compara ao volume de mortes ocasionadas pela inércia do Governo Federal no enfrentamento à pandemia de COVID-19.

De forma coerente com o caráter genocida de sua administração, as medidas do governo Bolsonaro para o trato dos temas que abordamos no presente texto também possuem na morte sua consequência mais extrema. Referimo-nos à sua inegável complacência com ações ilegais e violentas relacionadas ao agronegócio e à atividade mineradora, setores do capital cujos interesses, há décadas, provocam conflitos socioambientais no território nacional, em especial na Amazônia.

Bolsonaro teve explícito apoio do agronegócio e da mineração - que, juntos, constituem importante fração da burguesia nacional - e nos parece obstinado em resolver com celeridade, durante seu mandato, algumas das demandas mais essenciais destes setores para manter esse leque de alianças em seu próximo alvo: 2022. Parte dessas demandas tem a ver com a necessidade de ampliar a lucratividade da mineração predatória e do agronegócio, que se consolidam, a cada ano, como responsáveis pelos resultados positivos da balança comercial brasileira ao produzirem as principais commodities exportadas pelo país (minério de ferro, cobre, petróleo, soja, milho, açúcar, café e algodão). Nossa pretensão é demonstrar de que modo o governo Bolsonaro tem "pavimentado" o caminho para alcançar esse objetivo removendo dele quaisquer obstáculos legais. Tal premissa será demonstrada em nossa análise abordando um dos elos que conecta a lucratividade desses dois setores: a extração de potássio para produção de fertilizantes.

O Brasil importa mais de 90\% dos fertilizantes utilizados pelo agronegócio (MIRANDA; NASCIMENTO, 2015) e o potássio é um dos componentes decisivos para a produção desse insumo. Embora recentemente também tenha sido descoberto potencial de mineração de potássio no estado de Minas Gerais ${ }^{5}$ sua disponibilidade em território nacional está restrita às jazidas de sais de potássio, silvinita 
e carnalita presentes, predominantemente, nos estados de Sergipe e Amazonas (BRASIL, 2019). O iminente exaurimento das lavras hoje em exploração no estado de Sergipe tem ampliado o número de requerimentos de pesquisa ${ }^{6}$ (SIGMINE/ANM, 2021) e lavra ${ }^{7}$ desses minérios no Amazonas, onde se deparam com obstáculos legais relacionados à sua ocorrência em terras legalmente protegidas como terras públicas da União, Unidades de Conservação, territórios indígenas e quilombolas e assentamentos.

Exposto o núcleo de preocupações que originou o presente artigo e a direção política a ele conferida, cabe-nos mencionar que o desenvolvemos em quatro secções, além das considerações finais e dessa breve introdução. A primeira seção explora conceitualmente o tema da expropriação da terra fundamento teórico-conceitual e sócio-histórico comum à atividade mineradora e ao agronegócio no Brasil. Nesse sentido, percorre, a partir de uma leitura marxiana e marxista, algumas das marcas que fazem da expropriação não só um mecanismo presente na gênese do capital e sua acumulação primitiva, mas principalmente a torna essencial para sua reprodução ampliada na atualidade em função da crise em andamento. $\mathrm{Na}$ segunda seção, a centralidade é para uma caracterização do governo Bolsonaro e da atuação do Estado brasileiro para ampliar a reprodução do capital no território da Amazônia. Essa caracterização demonstra seus inequívocos compromissos com a mineração predatória e o agronegócio naturalizando a violência inerente a processos de expropriação e criminalização das lutas sociais.

Percorrida essa fundamentação, a terceira seção expõe as variáveis envolvidas na produção mineral de potássio no território amazonense e as ações do Governo Bolsonaro no âmbito do Poder legislativo para “abrir o caminho” à exploração de potássio em terras indígenas daquele estado - algo hoje constitucionalmente impedido. A quarta seção destaca os principais riscos e impactos que se mostram prováveis caso o projeto de exploração de minérios em terras indígenas seja aprovado pelo legislativo permitindo a operação de empreendimentos de extração de potássio no Amazonas que já possuem, inclusive, licenças emitidas. Nas considerações finais reforçamos algumas das premissas refletidas ao longo do texto e sua gravidade quando considerada a necessidade de respeitar os direitos humanos e a diversidade de modos de vida dos povos tradicionais que não podem ter sua existência ceifada por serem considerados "pedras no caminho" de um modelo de desenvolvimento que é parte de um projeto genocida.

\section{A expropriação como uma marca da formação econômica da Amazônia}

Os dados da economia ocultam frequentemente informações essenciais para a compreensão de sua materialidade na vida concreta dos cidadãos de um país. Assim se passa com os dados divulgados sobre a chamada balança comercial que se tornam positivos quando o volume de exportações supera o de importações. No caso brasileiro, dadas as características dos ramos de atividade econômica que respondem pelos principais itens exportados - a mineração predatória e o agronegócio - uma das verdades 
"ocultadas" pela divulgação dos dados é que ao fazê-lo, o Brasil está exportando recursos naturais em grande volume, sendo a terra (solo e subsolo) e a água os principais.

Outro dado ocultado quanto a isso é que para "exportar solo e subsolo" (GALEANO, 2010) por meio dessas atividades econômicas ocorre, constantemente, a expropriação de territórios de comunidades tradicionais. Esse processo se faz para transformá-los em áreas de exploração de megaempresas de extração de recursos naturais ou do agronegócio (monocultura e pecuária). No território brasileiro, a região amazônica foi historicamente saqueada pela ânsia do capital ${ }^{8}$, seja pela sua ocupação inicial em busca de produtos diretos da floresta amazônica (extração de borracha e madeira, por exemplo) ou pela biopirataria em busca de princípios ativos de plantas patenteadas pela indústria farmacêutica, entre outros vários recursos naturais apropriados privadamente. Atualmente, essa região é alvo de grandes empreendimentos do agronegócio e da mineração predatória que necessitam expulsar as comunidades tradicionais dos territórios ricos em recursos a serem potencializados por ambos os ramos da produção capitalista. Em outras palavras, a expropriação das comunidades tradicionais se constitui como modo contínuo de atuação do capital, revelando a necessidade constante do capital nacional e internacional em expandir seus domínios.

Esse processo de “[...] separação entre produtor e meio de produção [...]” (MARX, 2013, p. 786) se configura como expropriação, como uma necessidade de reprodução do capital que, de um lado, “[...] transforma em capital os meios sociais de subsistência e de produção e, por outro, converte os produtores diretos em trabalhadores assalariados." (MARX, 2013, p. 786). A expropriação requisita necessariamente o uso da violência para impor seus mecanismos históricos de "[...] separação entre os trabalhadores e a propriedade das condições da realização do trabalho.” (MARX, 2013, p. 786). Aos períodos iniciais da expropriação na história moderna, Marx (2013, p. 786) denominou "acumulação primitiva de capital"9. Nesse momento, a expropriação já se fazia para além do território europeu, por meio da colonização moderna e contando fundamentalmente com "a descoberta das terras auríferas e argentíferas na América, o extermínio, a escravização e o soterramento da população nativa nas minas, o começo da conquista e saqueio das Índias Orientais [...].”.

Os saques das riquezas naturais, inclusive no território da América Latina, portanto, fazem parte da "acumulação primitiva do capital" de países de capitalismo central e seguem, no curso da história, como mecanismos indispensáveis à sua reprodução ampliada.

$\mathrm{Na}$ fase inicial do capitalismo registra-se a extração e apropriação sem precedentes do ouro de Minas Gerais (Brasil) pela Inglaterra por intermédio de Portugal - minério que contribuiu para o enriquecimento e progresso inglês - e a extração de grande volume de prata em Potosí (Bolívia) e ouro no território de Tenochtitlán (México) pela Espanha. Dentre inúmeros outros recursos naturais pilhados, ocorreu o saque de guano e nitrato para o melhoramento do solo da agricultura capitalista, pois, em 1840, descobriram "[...] numerosas quantidades de nitrato de sódio [que] podiam ser extraídas do guano e do nitrato (nitro), os quais abundavam no Peru" (FOSTER; CLARK, 2006, p. 229), desencadeando uma 
corrida internacional pelo guano (FOSTER; CLARK, 2006). Para termos mensuração desta corrida, avistaram, em 1850, na costa do Peru, “[...] 44 barcos dos EUA, 40 da Inglaterra, cinco da França, dois da Holanda, um da Itália, um da Bélgica, um da Noruega, um da Suécia, um da Rússia, um da Armênia, e três do Peru [...]" (FOSTER; CLARK, 2006, p. 230) recheados com o guano. Após exaurirem o guano do solo latino, o nitrato, outro substrato útil a agricultura, ganhou importância na disputa internacional devido à sua potencialidade enquanto fertilizante ${ }^{10}$ (além da sua utilidade como componente de explosivos).

A apropriação, tanto de metais preciosos quanto de fertilizantes (guano e nitrato), contribuiu para o desenvolvimento do capitalismo nos principais países europeus sob o signo da violência, do massacre e do genocídio dos povos tradicionais da América Latina, além de guerras internacionais, como a Guerra do Pacífico (FOSTER; CLARK, 2006). Os saques aos recursos naturais foram contínuos perante o controle e dominação imperialista dos países centrais. A apropriação se tornou, cada vez mais, essencial para o desenvolvimento do capitalismo e, na era do capitalismo monopolista, se tornou concentrada nas mãos de pequenos grupos econômicos. Lenin (2011, p. 208-209) sinalizou, em 1917, que os

[...] monopólios adquirem a máxima solidez quando reúnem nas suas mãos todas as fontes de matérias-primas, e já vimos com que ardor as associações internacionais de capitalistas se esforçam por retirar ao adversário toda a possibilidade de concorrência, por adquirir, por exemplo, as terras que contêm minério de ferro, os jazigos de petróleo, etc.

O estágio imperialista subordina fortemente os países periféricos aos países centrais, principalmente para manter o controle "[...] das mais importantes fontes de matérias-primas, particularmente para a indústria fundamental e mais cartelizada da sociedade capitalista: a hulhífera [carvão de pedra] e a siderúrgica [aço e ferros fundidos]." (LENIN, 2011, p. 264) ${ }^{11}$. Os países centrais têm o controle direto do mercado financeiro e dos principais ramos industriais, além de dominarem fontes de matérias-primas dos países periféricos. Desde a "acumulação primitiva do capital", a extração e apropriação de recursos naturais são marcas históricas das economias dependentes e periféricas. "Algumas nações centrais dispõem de mais capital e controle de tecnologia (além de poder político e/ou militar). Configura-se uma situação na qual a dinâmica de uma nação ou região fica subordinada à dinâmica de outra nação/economia que se alimenta de parte do valor produzido na primeira." (MARQUES; MARQUES; ALVES, 2019, p. 10).

Conforme a divisão internacional do trabalho, os países periféricos historicamente tiveram a função de exportar produtos com pouco ou nenhum beneficiamento, como é o caso dos minérios e itens diretos provenientes da agropecuária. Com a crise estrutural do capital sob a égide da financerização da economia, estes foram remodelados sob a denominação de commodities, isto é, “[...] produtos primários ou semi-industrializados que tem padrão e cotação de preços no mercado mundial, sendo negociados em bolsas de valores e mercados futuros.

Nessa dinâmica econômica internacional, os países latinos se especializaram na exportação de minérios como cobre, ferro, prata, zinco etc., além do petróleo, que são fundamentais para indústria 
capitalista e abundantes nestes territórios. Ao questionar as marcas históricas da economia agrária e da atividade de mineração, que continuam latentes nos dias atuais nas nações latinas, principalmente no caso brasileiro, Galeano (2010), em 1971, indagou: “exportamos produtos ou exportamos solos e subsolos?”. Considerando-se essa rápida digressão histórica não nos parece restar dúvida de que os países latinos exportam, em sua maioria, "solo e subsolos".

As expropriações tomaram proporções avassaladoras a partir do estrondo da crise do capital da década de 1970, momento em que este ficou mais agressivo nos retrocessos de suas já limitadas possibilidades civilizatórias e passou a requerer novas e crescentes escalas de separação dos trabalhadores em relação aos meios de produção. Compreendemos, por meio de Fontes (2018, p. 21, grifos nossos), que “[...] os processos de expropriação não estão apenas na pré-história do capitalismo, mas também integram sua expansão, acompanhando a extensão das próprias relações sociais capitalistas e aprofundando-as [...].”. Assim, a expropriação é sistemática e necessária à reprodução do capital (FONTES, 2018).

Nesse contexto, a região da Amazônia tem sido fortemente alvejada. As expropriações nessa região sempre ocorreram sob mecanismos de extermínio, violência e expulsão de indígenas de suas terras, uma vez que a violência é fundamental para a "transformação de meios de vida em capital". (FONTES, 2018, p. 17). Atualizando mecanismos do período de acumulação primitiva, nos dias atuais a expropriação envolve ora a violência direta de grileiros, garimpeiros, latifundiários e empresas, ora a violência estatal, por meio dos mecanismos institucionais materializados na violência policial e/ou aparato jurídiconormativo-legal. Esses processos deixam sequelas na região amazônica, como "[...] trabalho escravo, usurpação de terras do Estado, expulsão de camponeses, índios e quilombolas, apropriação e mercantilização acentuada dos recursos naturais [...].” (MARQUES; MARQUES; ALVES, 2019, p. 18).

Desde a formação econômica do Brasil, a região Amazônica se caracterizou por uma economia extrativista, que somente foi remodelada com investimentos diretos do Estado brasileiro no período da ditadura empresarial-militar objetivando "capitalizar" e romper com o "atraso econômico" (MARQUES, 2012). Em decorrência disso a mineração predatória ganhou projeção na Amazônia com o II Plano Nacional de Desenvolvimento que a demarcou “[...] como 'fronteira de recursos naturais', destacadamente minerais; ou seja, colônia fornecedora de matéria-prima bruta aos países imperialistas." (MARQUES, 2012, p. 36). O Estado brasileiro passou a investir e favorecer diretamente a atividade mineral na Amazônia com mudanças legislativas que facilitaram a extração de minérios, como, por exemplo, o código de mineração de 1967 que abriu massivamente o território brasileiro para o capital estrangeiro e as multinacionais.

A tríade Estado brasileiro, burguesia nacional e capital internacional estava, assim, fortalecida para a exploração do solo e subsolo. Aquele se comprometeu com recursos públicos diretos para a conformação de uma infraestrutura (portos, rodovias, dutovias, aeroportos, hidrelétricas etc.) que assegurasse a fluidez da circulação dos recursos extraídos, conforme ocorreu na construção da rodovia 
Belém-Brasília (1958). Esta viabilizou a fluidez das mercadorias dentro do território nacional e, em especial, a exportação de ferro, cobre, caulim, manganês, bauxita etc.

O volume considerável de exportação de minérios da região amazônica somente foi possível com o investimento em mão de obra e tecnologias para a extração dos recursos naturais com mais eficiência e eficácia por parte de grandes empreendimentos da mineração. Cabe enfatizar, entretanto, que o alto teor tecnológico é utilizado somente para a extração, pois os minérios extraídos não possuem beneficiamento, o que confirma o “[...] o papel da região como uma colônia bio-energético-mineral. É o caso do ferro de Carajás, que é extraído, lavado e colocado nos trens que o levam ao porto no Maranhão para ser embarcado nos navios para o exterior.” (MARQUES, 2012, p. 40-41).

A centralidade na extração de minérios e fortalecimento das commodities na economia brasileira ganharam novas proporções com a "reprimarização" da economia tendo em vista o elevado crescimento de produtos primários e simultânea queda de produtos industrializados nos valores da exportação. A "reprimarização" faz parte do processo de mudanças na dinâmica do capitalismo brasileiro que se consolida com o estabelecimento de governos neoliberais. A "nova” relação estabelecida entre capital e Estado brasileiro foi sentida imediatamente com a aprovação parlamentar do “[...] fim do monopólio brasileiro sobre o subsolo (e suas riquezas), [...] e a aprovação da lei de patentes, através da qual o Brasil se comprometeu a pagar pela utilização de uma tecnologia ou procedimento que tenha sido patenteado por uma empresa em outro país.” (MARQUES, 2012, p. 40). Tivemos também a aprovação da Lei Kandir, em 1996, que “[...] isenta de ICMS os serviços e os bens primários, manufaturados e semimanufaturados destinados à exportação.” (TROCATE; COELHO, 2020, p. 59).

No decorrer dos últimos anos, diversas mudanças legislativas foram fundamentais para responder à "reprimarização" da economia com centralidade nas commoditeis agrícolas (soja, milho e trigo) e minerais. O Estado brasileiro favoreceu diretamente a esses setores, conforme apontamento de Trocate e Charles (2020, p. 57-58):

Em junho de 2013, o governo federal enviou ao Congresso o Projeto de Lei (PL) n. $5.807 / 2013$, que constituiria um Novo Marco Regulatório para a Mineração. Ainda no mesmo ano, foi criada uma Comissão Especial para avaliar o PL, cujo presidente foi o deputado Gabriel Guimarães (PT-MG), e cujo relator foi o deputado Leonardo Quintão (PMDB-MG). O projeto de lei enviado à Câmara dos Deputados em 2013 foi alterado, e seu último substitutivo foi apresentado em novembro de 2015 , não sendo aprovado. As principais mudanças na legislação federal relativa à mineração aconteceram por meio de três Medidas Provisórias (MP): MP n. 789/17, MP n. 790/17 e MP n. 791/17. A MP 789/17 alterou o cálculo da CFEM; a base do cálculo da CFEM era a receita líquida, isto é, a receita após o desconto dos tributos incidentes sobre comercialização, das despesas de transporte e dos seguros. Após o lançamento dessa Medida Provisória, convertida na Lei n. 13.540, de 2017, a base do cálculo passa a incidir sobre a receita bruta da venda, deduzidos os tributos incidentes sobre sua comercialização, pagos ou compensados, de acordo com os respectivos regimes tributários. A percentagem utilizada depende do mineral explorado, chegando ao máximo de até 3,5\%. A MP n. 790/17 e a MP n. 791/17 alteraram outras normas relativas à atividade mineradora e criaram a Agência Nacional de Mineração (ANM), em substituição ao Departamento Nacional de Produção Mineral (DNPM). 
Desse modo, sob o comando político e a agenda econômica do Governo Bolsonaro, esse quadro tem se aprofundado na direção da subserviência total do Estado brasileiro às demandas da mineração predatória e do agronegócio. É abundante o número de análises que denunciam tentativas de ampliar as áreas de exploração desses setores econômicos na região Amazônica coadunadas aos ataques desferidos sob direitos das comunidades tradicionais e expropriação de seus territórios, conforme veremos a seguir.

\section{A ofensiva radical do agronegócio e da mineração predatória na Amazônia sob o Governo}

\section{Bolsonaro}

A essência reacionária e conservadora da burguesia nacional e da classe média brasileira ganhou contornos mais explícitos com o projeto político e econômico liberal do Governo Bolsonaro. Esses contornos são marcados, entre outros traços, por uma subserviência "canina" aos ditames do capital internacional, pelo entreguismo das riquezas naturais e um discurso ideológico com expressões neofascistas que renovam preconceitos elitistas de toda ordem. A burguesia aderiu ao bolsonarismo para conter algumas tendências de movimentação popular e suas (tímidas) expressões em setores do Estado Nacional sob o comando do Lulismo. Na sua pauta, a necessidade de aprofundar as contrarreformas necessárias à acentuação da exploração da força de trabalho no Brasil, notadamente a contrarreforma da Previdência Social, e, no caso do agronegócio e da mineração predatória, de desregulamentar o máximo possível dispositivos que limitam sua expansão e lucratividade, fazendo "passar a boiada", na infeliz expressão do então ministro do Meio Ambiente do Governo Bolsonaro, Ricardo Salles.

Além da figura do Jair Messias Bolsonaro no comando político do Estado brasileiro, militares ascenderam em cargos diretos no governo - dez dos 22 ministérios são chefiados por militares reforçando o papel das forças armadas no comando do Estado (SILVA; ANTONINO, 2020). Somado a esta configuração, ainda tivemos o crescimento da bancada evangélica nos estados e no parlamento endossando a bancada BBB (Boi, Bíblia e Bala) - que oportunizou destacar pautas conservadoras e seu andamento no legislativo (ALMEIDA, 2019). O conservadorismo é um traço constitutivo histórico do capitalismo e da sociedade brasileira, que conforma o modus operandi do Estado e os projetos políticos hegemônicos das classes dominantes subalternas ao capital internacional.

Com traços neofascistas diante do contexto neoliberal, esse governo defende radicalmente a propriedade privada dos meios de produção e a "pátria", mas sem projeto de nação e submetida aos ditames do imperialismo norte-americano. Embora seja um governo de extrema-direita com discursos radicais contra os trabalhadores, “o modelo de desenvolvimento em implementação [...] não altera o projeto econômico, político e corporativo de reprodução do capital no contexto da globalização neoliberal.” (WANDERLEY; GONÇALVES; MILANEZ, 2020, p. 561), vigente nas últimas décadas. 
Debate

Podemos elencar como uma das principais características da economia política do Governo Bolsonaro as várias medidas editadas em benefício do agronegócio e dos projetos de mineração. Isso pode ser visualizado nas constantes tentativas de ampliação das áreas disponíveis para exploração desses setores avançando sob terras públicas da União, Unidades de Conservação, comunidades indígenas, quilombolas e assentamentos (ALENTEJANO, 2020). Esses territórios são estratégicos, tanto para o agronegócio como para a mineração, e seus ocupantes ou usos preservacionistas são considerados "[...] obstáculos a serem removidos, visando ampliar a oferta de terras no mercado que vive momento de intenso aquecimento." (ALENTEJANO, 2020, p. 367).

Um passo importante para ampliação das áreas do agronegócio é o Projeto de Lei 510/2122, ou "PL da grilagem", como uma demanda do agronegócio que pretende regular a posse de terras em áreas da União invadidas por grileiros. Esse PL tem como principal foco a Amazônia, atual território de “[...] interesses expansivos do agronegócio, pois é nela que se situa a maior parte das áreas públicas e comunitárias no país, encarada por este setor como fronteira a ser liberada para a plena expansão do agronegócio.” (ALENTEJANO, 2020, p. 369).

O governo possui diretrizes para ampliar a presença do capital no território da Amazônia ao elencar o agronegócio e mineração como prioridades. A centralidade do agronegócio na economia brasileira "[...] remonta ao segundo governo FHC, atravessou incólume os governos petistas e desaguou no governo golpista de Temer que, aliás, não existiria sem o apoio decisivo da bancada ruralista para o golpe jurídico-parlamentar-midiático que derrubou Dilma Roussef." (ALENTEJANO, 2020, p. 389). Desde o início da década de 1990 esses setores demandam constantemente vantagens no conjunto de políticas trabalhistas, ambientais, de infraestrutura, de ordenação sócio territorial e fundiário (ALENTEJANO, 2020) do Estado brasileiro. Em termos territoriais e fundiários, as principais commodities brasileiras (soja, cana e milho) concentram mais de 61,43 milhões de hectares, o que significa, na mesma medida, diminuição da área de plantio dos alimentos básicos dos brasileiros (feijão, arroz e mandioca) (ALENTEJANO, 2020) e revela a prioridade do uso das terras para o agronegócio exportador, deixando em plano secundário a produção de alimentos para os brasileiros ${ }^{13}$.

O agronegócio (monocultura e pecuária) e a mineração predatória avançaram consideravelmente sobre o território brasileiro e, no estágio atual do capitalismo requerem a expansão dos seus domínios, demandando novas terras para o capital na Amazônia, afetando consequentemente, a ocupação desse território tanto por meio de expropriação das comunidades tradicionais, quanto pelo bloqueio de novas titulações desse tipo. Tanto assim que a política fundiária sob este governo prioriza a "[...] suspensão de qualquer destinação de terras para a criação de assentamentos rurais, terras indígenas e territórios quilombolas [...]", além de criar formas de "[...] franquear as terras dos assentamentos e indígenas para a expansão do agronegócio e outros interesses do capital, como a mineração [...]”, e, conforme dispomos anteriormente, "[...] a intensificação da legalização da grilagem de terras, em especial na Amazônia." (ALENTEJANO, 2020, p. 365-366). Bolsonaro intensifica um processo que estava sendo desenhado 
desde o segundo governo Lula ${ }^{14}$ de redução drástica do número de assentamentos, ao ponto do seu governo praticamente aniquilar esta política agrária. Há também o abandono da política de homologação de Terras Indígenas (TIs) ${ }^{15}$, e a tendência da "[...] privatização das terras dos assentamentos e a abertura para a exploração privada das terras indígenas.” (ALENTEJANO, 2020, p. 378).

Desde o período de campanha eleitoral, Bolsonaro ataca constantemente os movimentos sociais vinculados às comunidades tradicionais encarando-os como entraves para o desenvolvimento econômico do país. Nas palavras de Alentejano (2020, p. 383), “[...] o governo Bolsonaro estabeleceu uma política deliberada de enfrentamento com estes movimentos, qualificando-os, mais do que como adversários políticos, como inimigos.”. Este cenário também possibilitou um ambiente confortável para garimpeiros, fazendeiros e grileiros ao ponto de sentirem-se cada vez mais seguros para promoverem ataques diretos e violentos às comunidades tradicionais, com aval do discurso ideológico do Presidente da República. De acordo com Wanderley, Gonçalves e Milanez (2020, p. 580), “em levantamento na mídia, no primeiro ano e meio de governo, ocorreram pelo menos 14 mobilizações de garimpeiros [...], onde foram recebidos pelo presidente", demonstrando crescente organização coletiva do setor em apoio as medidas do governo federal, enquanto os órgãos estatais, como a FUNAI, recebem as mobilizações indígenas com violência estatal sob o aparato da polícia.

É preciso destacar que a natureza violenta e autoritária do Estado brasileiro contra os povos tradicionais não é uma novidade, entretanto sua intensificação, radicalidade, ação aberta e direta, com uso do aparato normativo ${ }^{16}$, têm sido considerados como "novidades" sob o Governo Bolsonaro. O modus operandi do Estado brasileiro, sob esse governo, configura-se como "[...] coniventes com crimes; promotor de inconstitucionalidades, práticas antidemocráticas e fake news; além de realizador de ameaças recorrentes a opositores, às instituições da República e aos direitos das minorias." (WANDERLEY; GONÇALVES; MILANEZ, 2020, p. 556). Esse panorama define o estágio atual das investidas do capital contra os trabalhadores no Brasil, compostas por contrarreformas, recrudescimento severo dos direitos trabalhistas e sociais e repressão estatal contra as massas populares. Diante da repressão radical do Estado e desinibição dos grileiros, fazendeiros e garimpeiros, as lideranças dos movimentos sociais do campo têm orientado as comunidades tradicionais a evitarem "[...] confrontos diante das reiteradas promessas de repressão, do estímulo à violência por parte do governo Bolsonaro e da total falta de perspectiva de sucesso das ocupações [...].” (ALENTEJANO, 2020, p. 386-387).

Portanto, o agronegócio e mineração predatória encontraram "solo fértil" no Governo Bolsonaro para reforçar a "vocação agroexportadora" da economia brasileira (ALENTEJANO, 2020; WANDERLEY; GONÇALVES; MILANEZ, 2020). Ambos contam de um lado, com facilidades na tramitação de medidas legislativas que lhes favorecem, em especial quanto às intencionalidades de apropriação privada de terras e, de outro, com a redução da capacidade de fiscalização dos órgãos e agentes estatais, resultante de orçamentos profundamente contingenciados e décadas de sucateamento. Traçado esse panorama, avançaremos particularizando outros dos nexos que conectam interesses do 
agronegócio e da mineração no estado do Amazonas objetivando prospectar algumas de suas consequências, em especial, para os povos tradicionais.

\section{A mineração de potássio como um dos elos entre o agronegócio e a mineração predatória no}

\section{Brasil}

Por tudo que se disse anteriormente, é evidente o compromisso do governo Bolsonaro com ampliação das facilidades ofertadas em diversas frentes ao agronegócio e à mineração predatória. Suas pautas de desoneração fiscal, subsídios financeiros do sistema bancário público e condições mais favoráveis à suas operações tornam-se, rapidamente, pautas prioritárias do Executivo em nome do "interesse nacional" ou do "desenvolvimento". Essa retórica, fortemente ideológica, demonstra para qual fração de classe o Estado brasileiro governa. Lamentavelmente, se constitui uma simbiose de interesses com grandes chances de prosperar em suas reivindicações também no campo da regulação pública, operando, sem tréguas, na promoção de retrocessos que afetam profundamente o meio ambiente e os povos tradicionais.

Sabe-se que o agronegócio no Brasil se utiliza de tecnologia intensiva para produção baseada na monocultura de itens exportáveis e caracteriza-se

[...] fundamentalmente pela integração das cadeias produtivas que organizam a produção e circulação de mercadorias de origem agrícola em larga escala, comandadas por grandes empresas transnacionais que controlam os territórios. Tudo isso associado a um forte pacote tecnológico que inclui desde grandes máquinas agrícolas e pesquisa científica em áreas como genética e biotecnologia, ao uso intensivo de venenos e fertilizantes químicos, sistemas de transportes, além de um forte processo de financeirização da agricultura [...]. Representa, quase sempre, uma aliança de classe que associa latifundiários, empresas transnacionais, capital financeiro e mídia burguesa, com forte apoio de políticas de estado. (CHÃ, 2016, p. 30).

Trataremos, a partir daqui, de um dos elos dessa cadeia produtiva em suas conexões com a mineração. Referimo-nos aos lobbies para ampliação das condições nacionais de produção de fertilizantes - um dos elementos-chave da monocultura extensiva para exportação que vem sendo objeto de pressões pelo agronegócio e seus representantes no Executivo e no Legislativo, há pelo menos 25 anos.

Os fertilizantes, juntamente com os agrotóxicos (cuja utilização no Brasil também tem sido objeto de uma regulação pública cada vez mais permissiva), atuam a partir de combinações químicas, para potencializar a qualidade do solo - em geral desgastado e sem a reposição natural dos nutrientes, devido às características da monocultura. A produção de fertilizantes requer disponibilidade de nitrogênio (N), fósforo $(\mathrm{P})$ e potássio $(\mathrm{K})$ - os três macronutrientes principais no metabolismo vegetal - e é nesta demanda que os interesses do agronegócio e da mineração se fundem, pois, apesar da relativa abundância de fontes de nitrogênio e fósforo, a disponibilidade de potássio no país é bastante restrita. Jazidas expressivas de potássio foram identificadas, até o momento, apenas nos estados de Sergipe, Amazonas e, com recentes descobertas, em Minas Gerais (UHLEIN; MARQUES; UHLEIN, 2018) ${ }^{17}$, sendo lavradas somente no 
primeiro desses estados - onde opera também a fábrica produtora de fertilizantes responsável por $100 \%$ dessa produção no Brasil.

A extração de potássio em Sergipe é feita desde 1985 a partir da silvinita (rocha composta por cloretos de potássio e sódio) em uma única mina, a "Taquari-Vassouras", de propriedade da Petrobras e arrendada atualmente para a Vale que, por sua vez, vendeu suas operações relacionadas ao potássio para a "The Mosaic Company"18 desde 2017. As operações dessa mina encontram-se na iminência de encerrar-se por exaurimento do minério e, diante dessa previsão, desde o início dos anos 2000 foram sendo providenciadas ações para assegurar a instalação de um segundo projeto em Sergipe que desse continuidade a essa atividade. Trata-se do Projeto Carnalita, cuja licença de instalação já se encontra emitida para extrair potássio a partir de rochas contendo carnalita, um cloreto de potássio e magnésio. Embora esse minério não possua a mesma concentração de potássio que a silvinita, é reconhecido como o segundo mineral com melhor aproveitamento para essa finalidade. Entretanto, a região explorada está longe de atender a demanda brasileira por potássio que hoje provém, em mais de $90 \%$, da importação de países como Canadá, Alemanha e Bielorrússia (MIRANDA; NASCIMENTO, 2015).

Outro dado que nos parece importante destacar é que “[...] mais de 95\% da produção mundial de potássio é usada como fertilizante” (MIRANDA; NASCIMENTO, 2015, p. 4). Logo, evidencia-se que a mineração de potássio favorece diretamente o modelo nefasto de produção de alimentos baseado na monocultura e que, portanto, atende a interesses circunscritos ao circuito financeiro do agronegócio exportador e não à produção dos alimentos que chegam concretamente à mesa de brasileiros e brasileiras.

Voltando à situação atual da exploração do potássio e sua insuficiente disponibilidade para a produção de fertilizantes, os “olhos", tanto do agronegócio quanto da mineração, estão voltados para as reservas desse mineral existentes no estado do Amazonas. O histórico desse interesse é bastante antigo, mas nunca esteve tão perto de concretizar-se quanto na conjuntura do Governo Bolsonaro em face da correlação de forças extremamente favorável ao ideário da desregulamentação ambiental no âmbito do executivo e o legislativo federais.

A descoberta dessas jazidas de silvinita, carnalita e sais de potássio no território amazonense data do mesmo período das descobertas que levaram à abertura da mina “Taquari-Vassouras", em Sergipe. Originaram-se de uma série de pesquisas realizadas entre os anos 1970 e 1980 pela Petrobras, então empresa pública proprietária do monopólio de exploração do petróleo no Brasil, tendo por base o trabalho realizado Departamento Nacional de Produção Mineral (DNPM) através do Projeto Radar da Amazônia (RADAM). Nava (2019, p. 40) recupera essa história chamando atenção para

O Projeto Radar da Amazônia (RADAM), [anos 1970] que se constituiu no mapeamento regional multidisciplinar (geologia, geomorfologia, pedologia, vegetação e uso potencial da terra) [...] e, permitiu, com instrumentos novos (imagens de produtos de sensores remotos aerotransportados), a possibilidade de fotointerpretação, em detalhe, de domínios geológicos territoriais promissores à ocorrências minerais, que nos anos/décadas seguintes, se constituiriam em áreas onde estão situadas as principais 
minas em operação na Amazônia: Mina do Pitinga, Mina de Carajás, Mina de Porto Trombetas, dentre outras.

A busca principal da Petrobras era pelo petróleo, mas foram sendo obtidas concessões de lavra também para os demais minérios encontrados. No caso do potássio existente no Amazonas, a Agência Nacional de Mineração (ANM, antigo Departamento Nacional de Produção Mineral - DNPM) indica sete concessões de propriedade da Petrobras localizadas na Região do Rio Madeira, próximo à foz do Rio Amazonas, cujas portarias de lavra foram emitidas em 1984, mas que não se encontram em produção. Depois dos processos de privatização da Petrobras, nos anos 1990, a ex-estatal passou a arrendar seus ativos e subsidiárias, permitindo que monopólios de capital internacional ou associados ao capital nativo os operassem, usufruindo do "bônus" de já encontrarem "mapeadas" as ocorrências minerais. Ou seja, por meio dos "arrendamentos" promovidos pela Petrobras, o Estado brasileiro "entrega de mão beijada" esse potencial econômico ao capital financeiro, visto que todos os custos da pesquisa mineral - a fase mais “arriscada” e não lucrativa da mineração - foram assumidos pela empresa na condição de estatal.

Duas das jazidas de potássio no estado do Amazonas - localizadas no município de Nova Olinda do Norte (Fazendinha e Arari) - foram objeto da primeira Licitação Internacional dos Direitos Minerários realizada pela PETROBRAS em 200719. Naquela ocasião, entretanto, não foram apresentadas propostas para arrendamento, embora houvesse dez empresas inscritas no certame, sendo sete delas estrangeiras. Isso se explica, segundo Nava (2019), pelas incertezas quanto ao potencial das jazidas, descobertas na década de 1980 sem muitas das atuais ferramentas tecnológicas para pesquisa mineral. O ano seguinte (2008) registrou o "crescimento do número de requerimentos no DNPM, de novos pedidos de pesquisa mineral para silvinita, notadamente, nas áreas localizadas em polígonos adjacentes às jazidas Fazendinha e Arari, distribuídos ao longo das bacias hidrográficas do rio Madeira e rio Amazonas" (NAVA, 2019, p.113). Esse movimento "pavimentou” o sucesso da segunda licitação das mesmas áreas vencido pela Empresa de Mineração Falcon Metais Ltda, do Grupo Forbes \& Manhattan ${ }^{20}$, porém seu resultado foi objeto de destrato pela PETROBRAS em 15 de agosto de 2008. Reproduzimos a seguir a um trecho da pesquisa de Nava em que o mesmo recupera pronunciamento do atual Presidente da República sobre o tema:

O recente discurso do presidente da República Jair Messias Bolsonaro na reunião do Conselho Administrativo da SUFRAMA - CAS, em 25 de julho de 2019, resgata as discussões e pressão exercidas pelo Congresso Nacional sobre o tema, que justificariam a decisão do Governo Federal, através da PETROBRAS e sua Alta Administração, de solicitar o destrato e devolver os valores investidos na Licitação pela Falcon Metais Ltda [Empresa brasileira de Mineração, Razão Social Falcon Metais Ltda, CNPJ 09.451.327/0001-54, aberta em 18 de março de 2008, na cidade de Belo Horizonte (MG)] do Grupo Forbes \& Manhattan: 'Nós temos uma área riquíssima para potássio. E vale a pena aqui. Quando eu era deputado não poderia falar, porque as informações que eu obtive eram confidenciais. Como presidente, como agora eu sou dono desse carimbo, posso falar. [...] A PETROBRAS não foi apenas assaltada, de uma forma ou de outra. O direito à exclusividade para explorar potássio na foz do [...] rio Madeira foi vendido a empresa canadense em 2008. Vocês sabem quem era o presidente dessa época. E esse documento confidencial está comigo. Depois outras coisas aconteceram. 
Conseguimos, lá na frente, recuperar isso daí. Mas o Brasil foi vendido até dessa forma: a exclusividade de explorar subsolo nosso para empresas estrangeiras em documentos secretos. A nossa Amazônia é exuberante. Temos tudo aqui. Além do subsolo, como disseram, a biodiversidade, tenho mostrado, falado para o mundo, que qualquer país, que, porventura, queira, em parceria, explorar a nossa biodiversidade, estamos prontos para conversar com esses países. Tenho dito que a mesma coisa na exploração mineral. Nós não podemos viver apenas de commodities. Eu falo em parcerias que quero agregar valor aquilo que nós temos, e a Zona Franca de Manaus [...] é importante nessa, se Deus quiser, futura parceria para o bem-estar do nosso querido Brasil'. Discurso proferido pelo presidente da República do Brasil Jair Messias Bolsonaro na Reunião do CAS ocorrida em Manaus, Amazonas, em 25 de julho de 2019. (Degravação realizada em 08 de setembro de 2019). (NAVA, 2015, p. 115-116).

Embora falando confusamente, como lhe é característico, a mensagem que Bolsonaro emitiu nesse discurso objetivou relembrar uma crítica daquele momento vocalizada pelo Congresso Nacional à direção da PETROBRAS e aos governos petistas. Tal crítica relaciona-se, aparentemente, à venda desses ativos estratégicos de potássio a uma empresa de capital estrangeiro e que teriam pressionado a direção da PETROBRAS pelo destrato.

Não vamos adentrar essa polêmica aqui, haja visto que os objetivos de nossa reflexão referem-se à necessidade de visibilizar os riscos e impactos desse "território minado" para a população indígena. Porém, é impossível não notar em estudos de documentação e pesquisas a respeito da mineração as operações de "disfarce" da origem dos capitais investidos como um fato recorrente. A tentativa parece ser de dificultar as conexões existentes entre os interesses de grupos nativos e os monopólios internacionais do setor. Essa falsa polêmica, de verniz nacionalista, embora possa ter alguma importância no sentido de mapear o destino dos "saques" feitos na explotação dos recursos naturais, não é capaz, entretanto, de alterar o curso objetivo das questões que nos interessam chamar atenção aqui. Seja pelo capital nativo ou pela sua associação com os monopólios, o fato é que parece existir um certo consenso nas instâncias decisórias, quanto à necessidade de explorar esses ativos de potássio no estado do Amazonas. E quais são as "pedras no caminho" desse propósito?

O uso da expressão nesse momento de fato é metafórico, pois não estamos falando mesmo de "pedras" e sim de seres humanos "no caminho". O território hoje alvejado para exploração mineral de potássio na região amazônica é bastante próximo e, em alguns trechos se sobrepõe, a vários territórios indígenas demarcados ou em processo de demarcação. Por conseguinte, na ótica do capital interessado em avançar na extração de silvinita e demais minerais produtores de potássio, trata-se de remover o obstáculo legalmente existente por meio de regulamentação do $₫ 1^{\circ}$ do art. 176 e do $\ 3^{\circ}$ do art. 231 da Constituição de 1988.

A Constituição de 1988 não proíbe de modo absoluto a mineração em terras indígenas, conforme podemos ver na apreciação dos textos abaixo:

[...] Artigo 176 - As jazidas, em lavra ou não, e demais recursos minerais e os potenciais de energia hidráulica constituem propriedade distinta da do solo, para efeito de exploração ou aproveitamento, e pertencem à União, garantida ao 
Debate

concessionário a propriedade do produto da lavra. $\mathbb{S} \mathbf{1}^{\mathbf{0}}$ - A pesquisa e a lavra de recursos minerais e o aproveitamento dos potenciais a que se refere o "caput" deste artigo somente poderão ser efetuados mediante autorização ou concessão da União, no interesse nacional, por brasileiros ou empresa constituída sob as leis brasileiras e que tenha sua sede e administração no País, na forma da lei, que estabelecerá as condições específicas quando essas atividades se desenvolverem em faixa de fronteira ou terras indígenas $[. ..] ; \mathbb{S} 2^{\circ}-E$ Essegurada participação ao proprietário do solo nos resultados da lavra, na forma e no valor que dispuser a lei. [...] Artigo 231 - São reconhecidos aos índios sua organização social, costumes, línguas, crenças e tradições, e os direitos originários sobre as terras que tradicionalmente ocupam, competindo à União demarcá-las, proteger e fazer respeitar todos os seus bens. [...] $\mathbb{S} 2^{\mathbf{o}}$ As terras tradicionalmente ocupadas pelos índios destinamse a sua posse permanente, cabendo-lhes o usufruto exclusivo das riquezas do solo, dos rios e dos lagos nelas existentes. $\ 3^{\mathbf{0}} \mathbf{O}$ aproveitamento dos recursos hídricos, incluídos os potenciais energéticos, a pesquisa e a lavra das riquezas minerais em terras indígenas só podem ser efetivados com autorização do Congresso Nacional, ouvidas as comunidades afetadas, ficando-lhes assegurada participação nos resultados da lavra, na forma da lei. $\int 4^{\circ}$ As terras de que trata este artigo são inalienáveis e indisponíveis, e os direitos sobre elas, imprescritíveis. (BRASIL, 2016, n. p., grifos nossos).

Ao invés de uma proibição peremptória de lavra de recursos minerais em terras indígenas, o que vemos nos trechos negritados são as ressalvas que indicam a sua possibilidade, desde que obtida autorização do Congresso Nacional. O amparo para tanto reside na distinção entre a posse do solo e a propriedade do subsolo. Portanto, apesar de terras demarcadas na posse de grupos indígenas, entende-se que os recursos existentes em seu sobsolo são propriedade da União e, por essa razão, caberia ao Congresso fornecer autorização para os empreendimentos minerários. $O$ texto também informa a necessidade de ouvir as comunidades a serem afetadas - o que não significa que esse procedimento seja decisório para a autorização caracterizando-se, em geral, como apenas consultivo - e a necessidade de essas terem assegurada sua participação nos resultados da lavra.

Entretanto, inexiste até o momento lei que regulamente essa concessão pelo Congresso Nacional e, por essa razão, o lobby do agronegócio e da mineração é pela aprovação da referida regulamentação. Sem isso a ANM “[...] não autoriza pesquisa mineral em terras indígenas e, além de não autorizar, bloqueia as áreas em caso de demarcação da área indígena posterior à emissão da autorização de pesquisa ou concessão de lavra" (MIRANDA; NASCIMENTO, 2015, p.16).

Essa regulamentação vem sendo discutida na Câmara dos Deputados desde 1996, sendo a primeira das iniciativas existentes a do Projeto de Lei (PL) $\mathrm{n}^{\circ}$ 1.610, de 199621, de autoria do Senador Romero Jucá. Esse projeto que, ao longo dos anos, foi agregando propostas similares ${ }^{22}$, tramitou em uma comissão especial na Câmara dos Deputados formada para sua apreciação entre os anos de 2007 e 2019 com registro de várias atividades - inclusive audiências públicas contando com participação de entidades representantes dos povos indígenas. Essa comissão especial foi extinta em 2019, sendo que, neste mesmo ano, apresentaram-se dois requerimentos para sua recriação (em abril, pelo Deputado General Peternelli PSL-SP e em setembro pelo Deputado Luis Miranda - DEM/DF), mas até o momento os mesmos não foram votados. A explicação para esse fato pode residir no que relatamos a seguir: em 05 de maio de 2020 
o Poder Executivo apresentou o PL 191/2020, cujo objeto é o mesmo do PL 1.610/96. Isso pode significar que as articulações para elaboração desse novo PL já estavam em curso em 2019, o que poderia, por sua vez, tornar desnecessária reativação da Comissão Especial que apreciava o PL de 1996.

O PL 191/2020 é uma iniciativa da casa civil assinada por Bento Costa Lima Leite de Albuquerque Júnior e Sérgio Fernando Moro e apoia-se em parecer de 2016 do Tribunal de Contas da União (TCU) que cobra iniciativas do executivo para regulamentar esse dispositivo constitucional, além de atender, obviamente, às pressões do setor minerário para acelerar, por outras vias, a apreciação da matéria que tramita há 25 anos por meio do PL de Romero Jucá. O fato de ter sua origem no Executivo, confere ao projeto algumas prerrogativas em comparação com propostas apresentadas por parlamentares. A principal delas é a celeridade, com a possibilidade de ser apreciado em regime de prioridade significando que o PL tem reduzido em $3 / 4$ o seu tempo de tramitação.

Além da velocidade na sua tramitação, o potencial ofensivo dessa nova iniciativa é maior para a preservação de territórios indígenas também porque seu teor não se restringe à mineração. Esse PL pretende “[...] estabelecer as condições específicas para a realização da pesquisa e da lavra de [...] hidrocarbonetos e para o aproveitamento de recursos hídricos para geração de energia elétrica em terras indígenas [instituindo] indenização pela restrição do usufruto de terras [...]”. Ou seja, se a regulamentação do $\mathbb{J}$ $1^{\circ}$ do art. 176 e o $\int 3^{\circ}$ do art. 231 da Constituição resultar da aprovação desse PL não só o leque de atividades possivvel de ser autorizado pelo Congresso Nacional será ampliado como também estará normatizada a restrição de uso das terras indígenas mediante indenizações.

Relembrando os termos do discurso presidencial proferido em 2019 e citado acima, o "dono desse carimbo" não estava de bravata quando se arvorou, desde a campanha eleitoral, a questionar a legitimidade da ocupação dos territórios de povos tradicionais. Conforme explicitamos anteriormente, Bolsonaro nunca escondeu sua opinião contrária à novas titulações de terras indígenas ${ }^{23}$ e quilombolas, que se materializa em ações objetivas da política fundiária de reduzir drasticamente os assentamentos e a homologação de territórios indígenas, sendo "emblemático" o tratamento conferido em seu mandato à gestão dos órgãos públicos federais responsáveis pelos processos em questão: o INCRA, a FUNAI e a Fundação Palmares. Também não nos parece possível creditar a quaisquer "coincidências" a ocorrência, a partir de 2019, de incontáveis episódios de permissividade na destruição ambiental na região amazônica (incêndios, desmatamento acelerado, focos de garimpo ilegal, extração ilegal de madeira ${ }^{24}$, entre outros).

No caso em exame aqui, a autorização do Congresso Nacional para operações de extração de potássio em terras indígenas no estado do Amazonas, se concedida, atingirá primeira e imediatamente as terras e povos indígenas do município de Autazes ${ }^{25}$ - vez que já existe, para essa lavra, uma Licença Prévia emitida, conforme teremos ocasião de expor no item que se segue.

\section{Impactos da mineração para territórios indígenas na exploração do potássio na Amazônia}


O estado do Amazonas possui uma mina em operação para extração de estanho instalada desde 1981 na bacia hidrográfica do rio Uatumã, a Mina Pitinga. Sua história antecede a vigência de vários dos mecanismos ambientais instituídos após a promulgação do Sistema Nacional do Meio Ambiente (SISNAMA) e nos parece importante conhecê-la para vislumbrar, a partir de lições do passado, o que pode vir a ocorrer com a exploração de potássio num futuro breve.

Mesmo pesquisadores como Nava (2019), que demonstram uma certa “simpatia” pela ideia de regulação da exploração mineral em terras indígenas, desde que o modelo de mineração seja revisto com respeito à determinação legal de oitiva das comunidades e uma relação "mais sustentável" com as mesmas - o que nos parece, no mínimo, uma expectativa idealista, no mau sentido da palavra - são forçados a reconhecer o rastro de destruição socioambiental inerente a essa atividade produtiva. O estudo de Nava (2019) utiliza esse parâmetro de comparação entre o que pode ocorrer em Autazes (AM) e o que, de fato, ocorreu nas terras dos Waimiri-Atroaris em função da Mina Pitinga. Como resultado dessa comparação, o autor afirma categoricamente: "o paradigma Pitinga não nos serve”.

A primeira coisa que precisamos explicitar é que os impactos a serem considerados para o meio ambiente e os povos tradicionais devem ser dimensionados em sua totalidade. Um empreendimento de mineração requer disponibilidade de infraestrutura para produção e seu escoamento, por exemplo. Isso significa a instalação de outros empreendimentos de grande impacto socioambiental; no caso da mineração, disponibilidade de energia e água em abundância já que se trata de uma atividade intensiva na utilização desses recursos. Rodrigues e Fearnside (2015 apud NAVA, 2019, p. 168) mencionam alguns dos impactos prévios à operação propriamente dita da Mina Pitinga que recaíram sob o povo WaimiriAtroaris:

Para os militares a BR-174 era tão importante que teria de ser construída custasse o que pudesse custar aos Waimiri-Atroaris. [...] A população dos Waimiri-Atroaris foi estimada pela Funai em 3.000 indivíduos em 1972, e em 1974 (perto ao final da construção da BR-174), em entre 600 e 1.000 indivíduos (ver: SCHWADE; REIS, 2012, p. 5). A população continuou a diminuir e, em 1986, na época da construção da hidrelétrica de Balbina, era de apenas 374 indivíduos (ELETROBRAS, 1986, p. 6-12). O desaparecimento de pelo menos dois terços da tribo coincidiu com a construção da rodovia BR-174 pelo Exército Brasileiro, em 1973-1974. [...]. Há relatos contundentes da violência contra os Waimiri-Atroaris praticada pelo Exército brasileiro no ano de $1974[\ldots]$.

Como facilmente se deduz da leitura do trecho acima, embora a mina não seja dentro do território indígena, a utilização de água dos rios próximos para geração de energia e a construção da BR174 causaram um "efeito cascata” de difícil mensuração e um genocídio factual dessa população. Mas não foi só isso. Durante esses 40 anos de operação da Mina Pitinga, os conflitos socioambientais entre a empresa Paranapanema e os/as indígenas continuaram a se multiplicar. Além dos impactos na saúde e taxas de mortalidade por epidemias - que são bastante comuns quando indígenas passam a conviver muito proximamente com pessoas "brancas"- inúmeros enfretamentos ocorreram durante a construção das 
vicinais (estradas de ligação entre a BR e a região das minas) que cortam o território indígena; um conflito judicial foi processado em razão da ruptura de uma barragem em 1995, que afetou a qualidade da água do rio Alalaú e registram-se, ademais, as consequências do desmatamento no modo de vida da população indígena, cuja relação com a natureza é, como sabemos, vital em suas atividades extrativistas (como a caça, a pesca) e também culturais, a exemplo da ritualização de lugares instituídos como sagrados (NAVA, 2019).

Apesar dessa trágica evidência, o "consenso" obtido nas esferas do poder quanto à necessidade de permitir a mineração em terras indígenas e de ampliar a produção de potássio no Brasil explorando, a qualquer custo, as reservas do Amazonas está dado. Para parafrasear uma frase bastante utilizada pelo atual Presidente do Brasil26: "Agro acima de tudo, Minério acima de todos”. Não podem ser outras as razões que explicam a obtenção de uma Licença Prévia para que a "Potássio do Brasil" explore os achados de sua pesquisa na Jazida da Vila de Urucurituba, afetando 3 territórios indígenas da região de Autazes ${ }^{27}$. Devemos lembrar que esse mesmo grupo esteve envolvido na querela quanto ao destrato da Mina de Arari e Fazendinha pela Petrobras em 2008, mencionado no item anterior. O empreendimento ainda não teve início porque o Ministério Público suspendeu a Licença Prévia desde 2016 para que seja realizada a oitiva à população indígena Mura, residente nas áreas de influência direta e indireta da Mina (NAVA, 2019). Na atual conjuntura não vislumbramos, entretanto, indícios de que esse projeto possa ter sua instalação embargada.

De todo modo, nos chamou atenção a autorização de um projeto com as dimensões e impactos descritos no Relatório de Impactos Ambientais (RIMA) produzido pela "Potássio do Brasil" para requisição da Licença em comento. Veja-se que se trata de um documento de autoria da própria empresa, portanto, nada neutro quanto às intenções de minimizar a descrição dos referidos impactos para convencer analistas ambientais e populações afetadas. Apesar de longa, expomos a seguir uma citação indispensável desse RIMA na qual projeta-se o cenário dos impactos com a implantação do empreendimento considerando as fases de implantação, operação e futuro fechamento da mina:

'Meio Físico [...] [estima-se] um aumento na concentração de poeiras e gases. Essas alterações ocorrerão na etapa de implantação [...] no que se refere aos ruídos espera-se que na etapa de implantação hajam fontes de desconforto. A construção do porto tem o maior potencial para causar desconforto à população visto sua localização próxima à vila de Urucurituba. Na etapa de operação os barulhos devem ocorrer pelo funcionamento dos dispositivos de quebra do minério, pelo trânsito e operação de máquinas e equipamentos, pelo funcionamento da subestação elétrica e operações de movimentação de cargas no porto. $\mathrm{Na}$ etapa de fechamento haverá uma diminuição/encerramento das fontes de emissões acústicas e vibratórias do empreendimento. Em relação à qualidade das águas, [...] serão construídos sistemas de tratamento de águas e reservatórios de águas. [...] no que se refere às águas subterrâneas haverá interferência devido à construção dos poços de acesso à mina subterrânea [...] parte das águas salinas armazenadas em um reservatório será injetada em camadas profundas que já são salinizadas naturalmente e não possuem uso para os seres humanos. É assumida também a possibilidade de águas com grande teor de sal infiltrar nos aquíferos rasos próximos à área da planta alterando a qualidade dessas águas. As principais modificações do relevo serão causadas pela construção de um platô na área 
da planta. Meio Biótico [...]. Tem-se como aspecto inerente à sua instalação a redução dos ambientes naturais, contabilizada em 123,48 hectares, correspondentes a áreas de Floresta Amazônica em diversos estágios de regeneração. [...]. Com a implantação do empreendimento serão gerados impactos negativos e de alta significância sobre as comunidades da flora e fauna [...] Meio socioeconômico e cultural [...] O empreendimento irá provocar em Autazes uma profunda alteração econômica. [...]. No que tange à dimensão demográfica, Autazes passará a ser receptora. [...]. Na perspectiva do uso e ocupação do solo, o município de Autazes experimentará uma ampliação da sua área urbana [...]. Em relação à segurança pública, o número de ocorrências policiais tende a aumentar com o incremento da aglomeração urbana de Autazes [...]. Na perspectiva do saneamento básico, o município de Autazes terá que enfrentar e apresentar soluções ambientalmente orientadas no campo da distribuição e tratamento de água, da coleta e destinação dos resíduos sólidos e do tratamento de esgoto. [...] O empreendimento irá favorecer a elevação da renda, do acesso ao consumo e da qualidade de vida para amplos segmentos da população de Autazes, [...] abrindo oportunidades para novos investimentos ou dispondo para suas populações bens e serviços não acessíveis em suas territorialidades. (POTÁSSIO DO BRASIL, 2015 apud NAVA, 2019, p. 155-156)

Nos pareceu assustador que os órgãos ambientais tenham autorizado esse empreendimento, mas também não devemos esquecer que esse tipo de decisão, muitas vezes, tem derivado dos incontáveis episódios de assédio a trabalhadores(as) do IBAMA e ICMBio ${ }^{28}$, pressionando politicamente essas instâncias a emitirem pareceres favoráveis a empreendimentos que não possuem a menor condição de ser licenciados. Também em Nava (2019) existem depoimentos de analistas ambientais do estado do Amazonas advertindo que, em razão do sucateamento a que vem sendo submetido há décadas, o IPAAM não conseguirá acompanhar e fazer o controle ambiental de mais um projeto das dimensões já existentes no exemplo da Mina Pitinga.

O alerta está dado e não se trata de catastrofismo, conforme gosta de ironizar o chefe do Executivo brasileiro no momento. Não se pode assistir passivamente a essa naturalização do "desastre anunciado" que será a produção de potássio para o agronegócio no Amazonas. Nessa perspectiva somamo-nos às análises técnicas e científicas que denunciam essa situação fornecendo dados e informações para a luta que precisará ocorrer mais intensivamente contra esses projetos. Esse nos parece ser o conhecimento que faz sentido de ser produzido e difundido no tempo presente.

\section{Considerações finais}

Contextualizando o caráter conservador e de extrema direita do Governo Bolsonaro como um todo, o esforço desse texto dirige-se para pensar as conexões entre a gestão ambiental e a política econômica. Mais que nunca, o Estado brasileiro exerce seu papel regulador comprometendo-se com os interesses econômicos mais destrutivos de todas as formas de vida que estejam no caminho da lucratividade do capital. Exemplo emblemático dessa tendência é a gestão da pandemia de COVID-19 que já entra para a história mundial como algo absolutamente inaudito.

Essa tendência se espelha em todos os outros setores de gestão desse governo. Nos detivemos aqui a destacar um desses ângulos: a relação entre os interesses do agronegócio e da mineração predatória 


\section{Debate}

unificados na pressão sob o Executivo e o Legislativo para regular a exploração e explotação de potássio no Amazonas objetivando a produção de fertilizantes. Independente dessas ocorrências localizarem-se em territórios indígenas, esses processos tendem a avançar exemplificando o aprofundamento da expropriação de territórios de comunidades tradicionais pelo capital no Brasil, em especial, na região Amazônica. $\mathrm{Na}$ análise dessa situação esperamos ter deixado nítido que: 1. a meta alvejada é de reduzir os custos da produção do agronegócio exportador, diminuindo as importações de fertilizantes e, ao mesmo tempo, possibilitar a lucratividade do setor mineral explorando potássio; 2. só o capital ganhará com a realização desses investimentos; 3. haverá um rastro de destruição ambiental e humana que afetará diretamente os povos indígenas e também a população residente no entorno desses empreendimentos.

A dinâmica atual da centralização de capitais parece não conhecer limites no que diz respeito à apropriação da natureza, levando a um estágio ficcional o que poderia ser o mínimo de autonomia dos Estados Nacionais de países periféricos, cujos recursos naturais são alvo de um imperialismo cada vez mais ecologicamente predatório. $\mathrm{O}$ Governo Bolsonaro é parte dessa engrenagem funcional às necessidades da crise do capital e suas características mais nefastas no plano ideológico, materializadas nos ataques à democracia, aos direitos sociais e humanos não podem ser descoladas dessa análise que indica o essencial de sua movimentação no campo da política macroeconômica. Sua funcionalidade, ao colocar o "agro acima de tudo e o minério acima de todos" atualiza alianças históricas do Estado brasileiro com o latifúndio. Atualiza ainda a despreocupação com o tipo de "desenvolvimento insustentável" que também historicamente teve vigência no Brasil e evidencia a absoluta impossibilidade de conciliar projetos de mineração e a preservação de grupos humanos com as características dos povos tradicionais brasileiros, em especial, de povos das florestas, como os/as indígenas.

O resultado dessa trágica constatação é termos a população indígena brasileira reduzida a aproximadamente $0,47 \%$ da população total do país ${ }^{29}$, segundo dados do Censo IBGE de 2010. Esse contingente ocupa hoje apenas $11,6 \%$ do território nacional ${ }^{30}$ e, ainda assim, precisará lutar muito para não ser inteiramente dizimado por um projeto genocida que avalia esse tipo de custo como "contingências do desenvolvimento".

É necessário, entretanto, lembrar que o sangue que mancha esse minério e o agronegócio no Brasil não produz absolutamente nada de útil para a imensa maioria de brasileiros e brasileiras. $\mathrm{O}$ potássio da mineração transformado em fertilizante que potencializa as commodities agrícolas exportáveis não mata a fome da população brasileira que, aliás, cresceu assustadoramente no último ano em decorrência da pandemia e do projeto econômico do Governo Bolsonaro. Comida de verdade, que chega na nossa mesa, é produzida pela agricultura familiar e já se sabe disso a bastante tempo.

A produção do agronegócio, repleta se sangue do genocídio dos povos originários, só alimenta a engrenagem do capital, cuja história sempre esteve "inscrita nos anais da humanidade com traços de sangue e fogo" (MARX, 2013, p. 787). Portanto, nem tudo no governo Bolsonaro é novo e, não obstante suas características mais singulares, ele compõe uma universalidade mais ampla: a história do capitalismo. 
Essa sim, nos interessa escavar, mas para demonstrar seus limites e reconstruir, em outra direção, a relação homem-natureza a partir de parâmetros radicalmente humanos e respeitosos da nossa diversidade. Os povos indígenas têm muito a nos ensinar sobre isso e não podemos permitir que sua existência se transforme numa alegoria museológica dentro de um futuro breve.

\section{Referências:}

ALENTEJANO, Paulo Roberto Raposo. As políticas do Governo Bolsonaro para o campo: a contrarreforma agrária em marcha acelerada. Revista da ANPEGE, João Pessoa, v. 16. nº. 29, p. 353 392, 2020. Disponível em: https://ojs.ufgd.edu.br/index.php/anpege/article/view/12434 Acesso em: 10 abr. 2021

ALMEIDA, Ronaldo. Bolsonaro presidente: Conservadorismo, evangelismo e a crise brasileira. Novos estudos CEBRAP [online]. 2019, vol.38, n.1, pp.185-213. 2019. Disponível em: https://www.scielo.br/scielo.php?script=sci abstract\&pid=S010133002019000100010\&lng=en\&nrm=is o\&tlng=pt. Acesso em: 8 jul. 2020

ASSOCIAÇ̃̃O NACIONAL DOS SERVIDORES DE MEIO AMBIENTE (ASCEMA). Cronologia de um desastre anunciado: Ações do Governo Bolsonaro para desmontar as políticas de meio ambiente no Brasil. Brasília: 2020. Disponível em: https://www.biodiversidadla.org/Documentos/Cronologia-deum-desastre-anunciado-acoes-do-Governo-Bolsonaro-para-desmontar-as-politicas-de-Meio-Ambiente-noBrasil Acesso em: 30 abr. 2021.

BRASIL. Constituição Federal da República Federativa do Brasil. Disponível em : https://www2.senado.leg.br/bdsf/bitstream/handle/id/518231/CF88_Livro_EC91_2016.pdf Acesso em 20 abr. 2021.

BRASIL. Agência Nacional de Mineração. Sumário Mineral. Brasília: ANM, 2019. Disponível em: https://www.gov.br/anm/pt-br/centrais-de-conteudo/publicacoes/serie-estatisticas-e-economiamineral/sumario-mineral/sumariomineral 2017 Acesso em: 21 jul. 2021.

COMISSÃO PASTORAL DA TERRA. Conflitos ao campo: Brasil 2019. Goiânia: CPT Nacional, 2019. 247f. Disponível em: https://www.cptnacional.org.br/index.php/publicacoes-2/conflitos-no-campobrasil Acesso em: 20 jan. 2021

CHÃ, Ana Manuela de Jesus. Agronegócio e indústria cultural: estratégias das empresas para a construção da hegemonia. 159f. Dissertação (Mestrado em Geografia). Universidade Estadual Paulista, Programa de pós-graduação em Desenvolvimento Territorial na América Latina e Caribe. São Paulo: UNESP, 2016. Disponível em: https://repositorio.unesp.br/handle/11449/144217 Acesso em: 30 mar. 2021.

FONTES, Virginia. A transformação dos meios de existência em capital - expropriações, mercado e propriedade. In: BOSCHETTI, Ivanete (org.). Expropriação e direitos no capitalismo. São Paulo: Cortez, 2018.

FOSTER, John Bellamy; CLARK, Brett. Imperialismo ecológico: a maldição do capitalismo. In: PANITCH, Leo; LEYS, Colin (Editores). O Novo Desafio Imperial. Buenos Aires: CLACSO, 2006.

GALEANO, Eduardo. As Veias Abertas da América Latina. Rio de Janeiro: Paz e Terra, 2010.

LENIN, Vladimir Ilitch. O imperialismo: etapa superior do capitalismo. Campinas, SP: FE/UNICAMP, 2011.

MARQUES, Gilberto. Amazônia: uma moderna colônia energético-mineral? In: Universidade e Sociedade (Brasília), v. 49, p. 32-45, 2012. 
MARQUES, Indira Rocha; MARQUES, Gilberto de Souza; ALVES, Fernando Araújo. A apropriação de recursos naturais na Amazônia: dependência, espoliação e saque. In: A apropriação de recursos naturais na Amazônia: dependência, espoliação e saque, 2019, p. 99-108. Disponível em: https://sep.org.br/anais/2019/Sessoes-Ordinarias/Sessao3.Mesas21 30/Mesa30/303.pdf Acesso em: 20 mar. 2021.

MARX, Karl. O Capital: crítica da economia política. Livro I. São Paulo: Boitempo, 2013.

MARX, Karl. O Capital: crítica da economia política. Livro III. São Paulo: Boitempo, 2017.

MIRANDA, Luiz Almeida; Nascimento, Rodrigo Lima. Exploração de potássio no Brasil - Estudo. Brasília: Câmara dos Deputados. Setembro de 2015. Disponível em: https://bd.camara.leg.br/bd/bitstream/handle/bdcamara/25219/exploracao nascimento miranda.pdf?s equence $=1 \&$ is Allowed $=\mathrm{y}$. Acesso em 23 de mar.2021.

NAVA, Daniel Borges. Governança socioambiental local dos grandes projetos de mineração na Amazônia Ocidental brasileira. 257f. 2019. Tese (Ciências do Ambiente e Sustentabilidade na Amazônia). Universidade Federal do Amazonas, Programa de Pós-Graduação em Ciências do Ambiente e Sustentabilidade na Amazônia. Manaus: UFAM, 2019. Disponível em: https://tede.ufam.edu.br/bitstream/tede/7684/6/Tese DanielNava PPGCASA.pdf Acesso em 23 de mar. 2021.

SIGMINE. Sistema de Informação Geográfica da Mineração. Agência Nacional de Mineração. 2021. Disponível em: https://geo.anm.gov.br/portal/apps/webappviewer/index.html?id=6a8f5ccc4b6a4c2bba79759aa952d908 Acesso em: 21 mar. 2021.

SILVA, Everton Melo da; ANTONINO, Lucas Zenha. Os territórios da mineração não entram em quarentena! In: SANTOS NETO, Artur Bispo dos.; FERNANDES, Elaine Nunes Silva (orgs.). Coronavírus e crise do capital: impactos aos trabalhadores e à natureza. Goiânia GO: Editora Phillos Academy, 2020.

TROCATE, Charles; COELHO, Tádzio. Quando vier o silêncio: o problema mineral brasileiro. São Paulo: Expressão Popular, 2020.

UHLEIN, Alexandre; MARQUES, C. S. S.; UHLEIN, G. J. Fertilizantes provenientes de depósitos sedimentares de fosfato e de potássio pré-cambrianos. In: SOARES, Antônio Carlos Pedrosa; VOLL, Eliane; CAMPOS, Edson. (Org.). Recursos Minerais de Minas Gerais Online. Belo Horizonte: CODEMGE, 2018, v. 1, p. 1-18.

WANDERLEY, Luiz Jardim; GONÇALVES, Ricardo Junior de Assis Fernandes; MILANEZ, Bruno. Revista da ANPEGE, João Pessoa, v. 16. no. 29, p. 555 - 599, 2020. Disponível em: https://ojs.ufgd.edu.br/index.php/anpege . Acesso em: 10 abr. 2021

\footnotetext{
Notas

${ }^{1}$ Doutora em Serviço Social pela Universidade Federal do Rio de Janeiro (2008). Mestra em Serviço Social pela Universidade Federal do Rio de Janeiro (2000). Graduação em Serviço Social pela Universidade Federal de Sergipe (1996). É professora associada do Departamento de Serviço Social da Universidade Federal de Sergipe. Tem experiência de ensino na graduação e pósgraduação em Serviço Social e mais recentemente desenvolve pesquisas na área de Serviço Social e da questão ambiental vinculadas ao Grupo de Estudos e Pesquisas Marxistas (GEPEM/UFS). Lattes: http://lattes.cnpq.br/8335263833143569 Orcid http://orcid.org/0000-0001-6846-4424 E-mail: josissse@gmail.com

2 Mestre em Serviço Social pela Universidade Federal de Alagoas (2016). Graduação em Serviço Social pela Universidade Federal de Sergipe/UFS (2014). Atualmente é doutorando em Serviço Social no Programa de Pós-graduação em Serviço Social da UFAL.
} 
Foi docente titular do Centro Universitário AGES (UniAGES), no curso de Serviço Social, e Professor substituto da Universidade Federal de Sergipe (UFS) no Departamento de Serviço Social (DSS/UFS). Estado, Estado brasileiro, "questão ambiental", trabalho e relações sociais e Serviço Social são as principais áreas/linhas de investigação. É membro do Grupo de Estudos e Pesquisas Marxistas - GEPEM/UFS, nas linhas de pesquisa: Marxismo e Questão ambiental; e ética, política e marxismo. Lattes:

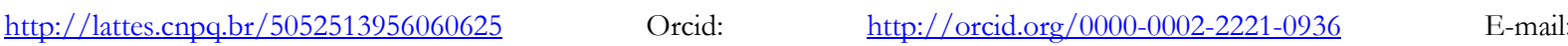
evertonmsilva@outlook.com.br

${ }^{3}$ Em 2020, o Brasil registrou 2.291 mortes a mais comparado ao registrado no ano anterior. No total, foram 50.033 mortes em 2020 (no contexto da pandemia) e 47.742 em 2019, conforme apontou a reportagem do G1/SP. Disponível em: https://g1.globo.com/sp/sao-paulo/noticia/2021/07/15/brasil-teve-50-mil-mortes-violentas-em-2020-um-aumento-de5percent-em-plena-pandemia-apos-dois-anos-de-queda-mostra-anuario.ghtml Acesso em: 22 jul. 2021.

${ }^{4} \mathrm{O}$ campo brasileiro também tem sido palco do aumento da violência de garimpeiros, fazendeiros e grileiros contra assentados, comunidades indígenas e quilombolas. Aqueles grupos passaram a reconhecer no discurso violento do Presidente um certo apoio as suas ações na "defesa da propriedade" coadunado com a ampliação do acesso a armas de fogo. A Comissão Pastoral da Terra divulgou que, em 2019, ocorreram 1.833 conflitos no campo, o maior já registrado (CPT, 2019).

5 Os "achados" de potássio em Minas Gerais se encontram no município de Matutina. Além disso, foi encontrado fosfato nos municípios de Quartel Geral, Cedro do Abaeté, Conceição do Mato Dentro, Lagamar, Patos de Minas e Coromandel (UHLEIN; MARQUES; UHLEIN, 2018).

${ }^{6}$ De acordo com o SIGMINE/ANM (2021), entre os anos de 2010-2020, empresas obtiveram autorizações de pesquisa sobre sais de potássio no território sergipano, cerca de 23 autorizações, especialmente nos anos de 2010 e 2011 . As principais empresas que adquiriram autorizações foram Itaguassu Agro Industrial, Phosfaz Fertilizantes e Triunfo Mineração do Brasil.

7 Segundo Nava (2019, p. 150-151), "existiam 983 processos de direitos minerários ativos referentes à exploração de minerais utilizados para produção de potássio fertilizante (silvinita, carnalita e sais de potássios). [...] . Além das concessões de lavra da Petrobras, existem ativos 361 processos de Autorização de Pesquisa para exploração de silvinita e sais de potássio na Amazônia. Grande parte das áreas onde estão sendo desenvolvidas as pesquisas para exploração de silvinita e sais de potássio se localizam ao redor das áreas de concessão da Petrobras. Além dos processos com Autorização de Pesquisa, existem mais 87 Requerimentos de Pesquisa para exploração de silvinita e sais de potássio em Amazonas."

8 A região do centro-oeste é marcada pela histórica concentração de terras (latifúndio) e expulsão de camponeses e roubos de terras públicas.

9 Marx (2013, p. 786), em “O capital: crítica da economia política”, demonstrou, em 1867, o processo de separação dos trabalhadores dos meios de produção através da análise das transformações econômicas, políticas e sociais da Inglaterra que ocorreram a partir do século XIV. Ele denomina de "acumulação primitiva do capital" "[...] porque constitui a pré-história do capital e do modo de produção que lhe corresponde.".

${ }_{10}$ A Europa explorou e praticamente exauriu o guano dos países latinos. A retirada dos substratos da natureza do território latino para o território europeu contribuiu para a amplificação da "falha metabólica" posta pelo capitalismo na medida em que retira as potencialidades e nutrientes de um local e transporta para outro e impossibilita a natureza de se recompor. Nas palavras de Marx (2017, p. 873, grifos nossos), “[...] a grande propriedade do solo reduz a população agrícola a um mínimo em diminuição constante e opõe-lhe uma população industrial cada vez maior, aglomerada em grandes cidades, gerando assim as condičoes para uma ruptura irremediável no metabolismo social, prescrito pelas leis naturais da vida; [...]. A indústria e a agricultura em grande escala, exploradas de modo industrial, atuam de forma conjunta. Se num primeiro momento elas se distinguem pelo fato de que a primeira devasta e destrói mais a força de trabalho e, com isso, a força natural do homem, ao passo que a segunda depreda mais diretamente a força natural da terra, posteriormente, no curso do desenvolvimento, ambas se dão as mãos, uma vez que o sistema industrial na zona rural também exaure os trabalhadores, enquanto a indústria e o comércio, por sua vez, fornecem à agricultura os meios para o esgotamento do solo."

11 "Para o capital financeiro não são apenas as fontes de matérias-primas já descobertas que têm importância, mas também as possíveis, pois a técnica avança, nos nossos dias, com uma rapidez incrível, e as terras hoje não aproveitáveis podem tomar-se amanhã terras úteis, se forem descobertos novos métodos (para cujo efeito um banco importante pode enviar uma expedição especial de engenheiros, agrônomos, etc.), se forem investidos grandes capitais. O mesmo acontece com a exploração de riquezas minerais, com os novos métodos de elaboração e utilização de tais ou tais matérias-primas, etc. etc. Daí a tendência inevitável do capital financeiro para ampliar o seu território econômico e até o seu território em geral.” (LENIN, 2011, p. 210).

12 Este Projeto de Lei é uma derivação da Medida Provisória 910/19 ou "MP da Grilagem". "Mas Bolsonaro não foi o único a propor, nos últimos anos, ações favoráveis à grilagem de terras. Lula e Temer também o fizeram.” (ALENTEJANO, 2020, p. 381).

${ }^{13}$ A pecuária também aumentou a área de ocupação, principalmente com avanços significativos para Amazônia.

14 "Nada menos que 52,1\% das desapropriações de terra foram realizadas nos governos FHC, 29,3\% nos governos Lula e na atual década menos de 4\% do total. Dilma, em seis anos de governo, desapropriou menos terras que Itamar em dois anos, no governo Temer foram apenas cinco desapropriações e nenhuma sob Bolsonaro [...].” (ALENTEJANO, 2020, p. 373). 
15 “Quando consideramos a área destas TIs, o período com maior área homologada foi o dos governos FHC, com 37,7\% do total, pouco mais que os $37,2 \%$ do período Sarney/Collor. Já nos governos Lula o percentual foi bem menor, apenas $17,2 \%$ do total. Na década de 2010, nos governos Dilma, Temer e Bolsonaro foram meros 3\%, menos que nos dois anos do governo Itamar." (ALENTEJANO, 2020, p. 374).

16 “[...] Bolsonaro foi pioneiro em estimular abertamente tais práticas e buscar mecanismos de sua legitimação.” (ALENTEJANO, 2020, p. 389).

17 "Existem indicativos de reservas de potássio em Minas Gerais. Entretanto, as reservas de Minas Gerais são de rochas silicáticas alcalinas, necessitando ainda de desenvolvimento de tecnologia para seu aproveitamento econômico na produção de fertilizantes" (MIRANDA; NASCIMENTO, 2015, p. 15).

18 Trata-se de uma empresa de capital norte-americano.

19 A jazida de Fazendinha continua em posse da PETROBRAS. Nava (2019) elenca, entretanto, processos recentes de pesquisas minerais no entorno da jazida de Arari, também ainda pertencente à Petrobras. Uma das lavras encontradas em decorrência disso data de 2013 e foi denominada como "Jazida Vila de Urucurituba". Esta localiza-se no município de Autazes, e pertence à empresa Potássio do Brasil que possui Licença Prévia para o empreendimento emitida pelo Instituto de Proteção Ambiental do Amazonas (IPAAM) desde 2015

20 "A Sede do Grupo Forbes Manhattan fica em Toronto no Canadá, e a principal fonte de recursos financeiros e de investimentos de risco no desenvolvimento/implantação de novos projetos de Mineração, inclusive àqueles relacionados as reservas de Fazendinha/Arari, são captados na Bolsa de Valores de Toronto" (NAVA, 2019, p.114).

${ }^{21}$ A ementa do PL n ${ }^{\circ}$ 1.610/1996 dispõe "sobre a exploração e o aproveitamento de recursos minerais em terras indígenas, de que tratam os arts. 176, parágrafo $1^{\circ}$, e 231, parágrafo $3^{\circ}$, da Constituição Federal".

22 Em levantamento recente efetuado no site da Câmara dos Deputados identificamos sete Projetos de Lei apensados. São eles: 7.099/2006; 7.301/2006; 5.265/2009; 3.509/2015; 5.335/2016; 4.447/2019 e o PL-1737/2020.

${ }^{23}$ Em 2017, Bolsonaro em campanha afirmou sobre os territórios indígenas que "não terá um centímetro quadrado demarcado" e, em 2018, já eleito, voltou a afirmar: "Eu tenho falado que, no que depender de mim, não tem mais demarcação de terra indígena. [...] Um fazendeiro não pode acordar hoje e, de repente, tomar conhecimento, via portaria, que ele vai perder sua fazenda para uma nova terra indígena." Disponível em: https://www1.folha.uol.com.br/poder/2018/11/no-que-depender-demim-nao-tem-mais-demarcacao-de-terra-indigena-diz-bolsonaro-a-tv.shtml Acesso em: 22 maio 2021

${ }^{24}$ Em dezembro de 2020, a Política Federal fez a maior apreensão de madeira extraída ilegalmente na região Amazônica - 65 mil árvores de espécies como ipê, maçaranduba, cumaru, angelim -, episódio que contou com a interferência direta de Ricardo Salles (Ministro do Meio Ambiente) para a liberação da madeira em compromisso com os empresários madereiros. Informações retiradas do site: https://www.dw.com/pt-br/fraudes-grotescas-diz-delegado-sobre-madeira-ilegal-que-salles-quer-liberar/a$\underline{57391991}$ Acesso em: 29 maio 2021.

25 É importante lembrar ainda que as áreas que já possuem confirmação de minérios em regiões próximas às reservas indígenas não dependem dessa autorização do Congresso Nacional para terem iniciadas as operações de extração. Isso significa sublinhar que também podem impactar terras indígenas adjacentes.

26 "Brasil acima de tudo, Deus acima de todos".

27 De acordo com dados da FUNAI (apud NAVA, 2019) as Terras Indígenas próximas ao Projeto da "Potássio do Brasil" em Autazes são: Paracuhuba, Jauary e Guapenu.

28 A Associação Nacional dos Servidores de Meio Ambiente produziu um excelente dossiê documentando o desmonte dos órgãos ambientais no período do governo Bolsonaro (ASCEMA, 2020). Vale conhecer o documento que traz links das notícias relacionadas a medidas desse período com impactos negativos na gestão do meio ambiente no Brasil, na situação orçamentária dos órgãos ambientais e também denúncias trabalhistas envolvendo os episódios de assédio e interferência política nas análises técnicas.

${ }^{29}$ Disponível em: https://pib.socioambiental.org/pt/Quantos s\%C3\%A3o\%3F Acesso em: 20 maio 2021.

30 Disponível em: https://brasil500anos.ibge.gov.br/territorio-brasileiro-e-povoamento/historia-indigena/terrasindigenas.html\#: :text=As $\% 20$ terras $\% 20$ ind $\% \mathrm{C} 3 \% \mathrm{ADgenas} \% 20 \mathrm{ocupam} \% 20 \mathrm{cerca}, 8.547 .403 \% 2 \mathrm{C} 5 \% 20 \mathrm{~km} 2 . \quad$ Acesso em: 20 maio 2021 . 